\title{
EDITORIAL
}

\section{Editorial: Journal of Cultural Analysis and Social Change}

\author{
Simon Stewart ${ }^{1 *}$ \\ ${ }^{1}$ University of Portsmouth, UNITED KINGDOM \\ *Corresponding Author: simon.stewart@port.ac.uk \\ Citation: Stewart, S. (2018). Editorial: Journal of Cultural Analysis and Social Change, Journal of Cultural \\ Analysis and Social Change, 3(1), 07. https://doi.org/10.20897/jcasc/3118
}

Published: August 9, 2018

Keywords: cultural analysis, social change, culture

Journal of Cultural Analysis and Social Change (JCASC) is an international, interdisciplinary peer-reviewed and open access journal. It has emerged from the ashes of the short-lived European Journal of Sociology and Anthropology, which only published a few articles. When I heard that there was an opportunity to launch a new journal, I had not been thinking of taking on an Editorship. However, I sensed a great opportunity. I changed the title of the journal, recomposed the Editorial Board and re-wrote the journal's Aims and Scope. The new journal provides a chance to publish and promote excellent cultural analysis from a range of perspectives. While institutional constraints mean that many journals have a predominantly national focus, I saw this journal's open access platform as a means of opening up critical discourse, debate and discussion to an international readership and encouraging article submissions from around the world. The Editorial Board of this journal now consists of over forty members from sixteen different countries. In the first few months of the journal's existence, we have had submissions from twenty one countries.

JCASC welcomes innovative and original conceptual and empirical research drawn from a number of disciplines including sociology, social theory, cultural studies, history, cultural anthropology, gender studies and media studies. The expertise on the Editorial Board reflects these core areas. Rather than attempting to identify specific contributions the journal can make to each of these fields, I will make a few general points about its focus. The conception of culture that the journal adopts is necessarily broad. It encompasses culture in its restrictive and more general senses, with its focus on the arts and popular culture, and culture as a way of life (Williams, 1981). It welcomes research on the political economy of culture industries but also analysis that takes cultural autonomy as its starting point and considers culture to be an independent variable (Rasul and Proffitt, 2017; Alexander, 2003). JCASC is attentive to research that treats culture as a resource and examines the institutional structures, 'diversity deficits' and power dynamics within the various regions of each cultural field (Bourdieu, 1993; Squires, 2017). At the same time, the journal does not shy away from considering normative questions of value, whether ethical or aesthetic (Stewart, 2012, 2017; Wolff, 2006, 2008). Alongside scholarship on the arts and popular culture, the journal foregrounds work on culture in its broader sense, including research on values, beliefs, ideas, practices, symbolic boundaries, identities and modes of being and belonging, whether those of the dominant or dominated, majority cultures or diasporic groups. It explores the fate of those on the fringes of the global order, those occupying liminal spaces, forced to be on the move and adapt to new contexts in our increasingly polarized, disjunctive global order (Appadurai, 1990; Erel, 2010; Sayad, 2004). It asks who has the authority to attribute value and considers the ways in which this can be contested (Skeggs, 2004; Lawler, 2005). At a more philosophical level, it allows for critical scrutiny of the tension between our subjectivity and the totality of knowledge, the objective culture that towers above us as individuals and from which we can only draw so much (Simmel, 2004[1900]). The journal welcomes research that deals with culture and meaning, focusing on key existential questions with which we are confronted in these uncertain times. Along these lines, as John Carroll $(2008$, p. 4) puts it, culture 'is those myths, 
stories, images, rhythms, and conversations that voice the eternal and difficult truths on which deep knowing, and therefore wellbeing, is dependent'.

The journal is oriented towards (but not limited to) research on social change, thus imbuing it with a political dimension and purpose. By providing a forum for critical dialogue, it is the intention of this journal to encourage cultural analysis that challenges the ideological fashions and injustices of the day and in doing so, contributes to wider debates and helps to stimulate new and progressive forms of social engagement. Rather than wishing away complexity, it seeks to put forward nuanced, historically-sensitive research that considers the complex transformations that have framed our lives (Inglis, 2014). It asks why things are as they are and how they might be different. Our times are beset with a sense of insecurity caused in great part by global inequality, the polarization of wealth and life chances, and a neglect of environmental issues. Technological innovations continue to transform our experiences of culture and the ways in which it is created, communicated, reproduced and reconstituted. Meanwhile, it seems that many mainstream commentators are confident that their view of the world is the sensible, correct view and that anything else is 'ideological'. This journal seeks to challenge such complacency and endeavours to open up a space within which alternative ways of viewing the world can be formulated and developed. It will provide a forum within which to facilitate dialogue and debate conducted with the spirit of transborder solidarity. JCASC can play a role in cross-cultural communication and also as a means of defence against the violence of exclusionary politics and the consequences of neoliberalism. With its emphasis on imaginative work with a critical focus, the Journal of Cultural Analysis and Social Change seeks to open up debate and discussion across borders and disciplines.

This first issue has come together rather quickly. The journal launched in January 2018 and this issue was published in early August 2018. The peer-review process is swifter at this journal than at most, but nevertheless, it was a rush to get the first batch of articles ready. It is great to see that the first issue starts as we wish to proceed: it features six original and innovative articles; two of these are extended pieces. While there is no unifying theme connecting the articles, each one speaks, in some way or other, to the journal's Aims and Scope.

\section{Simon Stewart University of Portsmouth, UK Editor-in-Chief}

\section{REFERENCES}

Alexander, J. (2003). The Meanings of Social Life: A Cultural Sociology. Oxford: Oxford University Press. https://doi.org/10.1093/acprof:oso/9780195160840.001.0001

Appadurai, A. (1996). Modernity at Large: Cultural Dimensions of Globalization. Minneapolis: University of Minnesota Press.

Bourdieu, P. (1993). The Field of Cultural Production: Essays on Art and Literature. Cambridge: Polity Press.

Carroll, J. (2008). Ego and Soul: The Modern West in Search of Meaning. Berkeley, CA: Counterpoint.

Erel, U. (2009). Migrant Women Transforming Citizenship: Life Stories from Britain and Germany. London: Routledge.

Inglis, D. (2014). What is Worth Defending in Sociology today? Presentism, Historical Vision and the Uses of Sociology. Cultural Sociology, 8(1), 99-118. https:// doi.org/10.1177/1749975512473288

Lawler, S. (2005). Disgusted Subjects: The Making of Middle-Class Subjectivities. Sociological Review, 53(3), 429-446. https://doi.org/10.1111/j.1467-954X.2005.00560.x

Rasul, A. and Proffitt, J. M. (2017). Promoting patriotism through mediated sports: Political economy of Bollywood sports movies. The Communication Review, 20(4), 225-245. https://doi.org/10.1080/10714421.2017.1377373

Sayad, A. (2004). The Suffering of the Immigrant. Cambridge: Polity.

Skeggs, B. (2004). Class, Self, Culture. London: Routledge.

Simmel, G. (2004[1900]). The Philosophy of Money. London: Routledge.

Squires, C. (2017). Publishing's diversity deficit. CAMEo Cuts \#2. Research Institute for Cultural and Media Economies, University of Leicester.

Stewart, S. (2012). Reflections on sociology and aesthetic value. Distinktion: Journal of Social Theory, 13(2), 153-167. https://doi.org/10.1080/1600910X.2011.613483

Stewart, S. (2017). Evaluative judgements: ethics, aesthetics and 'bad taste'. The Sociological Review, 65(1), 37-51. https://doi.org/10.1111/1467-954X.12360

Williams, R. (1981). Culture. London: Fontana.

Wolff, J. (2006). Groundless Beauty: Feminism and the Aesthetics of Uncertainty. Feminist Theory, 7(2), 143-158. https://doi.org/10.1177/1464700106064407

Wolff, J. (2008). The Aesthetics of Uncertainty. New York: Columbia University Press. 